( 2)

\title{
ボールバウンシング動作の速度と熟練度の違いが 関節スティフネスに及ぼす影響
}

\author{
岩見雅人 ${ }^{\dagger}$, 木塚朝博 \\ 筑波大学大学院 人間総合科学研究科
}

要旨 ボールバウンシング動作は種々の球技で用いられるスキルであり，運動協調性を評価する 上でも有用な動作課題とされている。しかし，その動作速度や熟練度の違いを運動学的，電気生 理学的な指標から検討した研究はほとんどみられない, そこで本研究では, 熟練度の異なる被験 者に対して 3 つ異なる速度条件でボールバウンシング動作を実施させ, 運動学的, 電気生理学 的デー夕の変化を捉えた。 その結果, 動作速度の増加に伴い関節の角度変位量と筋活動様相の関 係性が変化し，またその変化様相は熟練度によって異なっていた。これらの速度条件による変化 や熟練度の相違は制御戦略の違いを表しており, 熟練群は各速度条件に対して合目的的に関節ス ティフネスを調節していることが示唆された.

キーワード：ボールバウンシング動作, 速度条件, 筋電図, 同時収縮, 関節スティフネス

\section{1.はじめに}

日常動作やスポーツ動作における多種多様な動き は，その目的や環境の変化に応じた動作速度で実行 されている，動作速度の変化に伴い，四肢の運動制 御様式は速度依存的に調整され，より合目的的な動 作が遂行されることはよく知られている.

実際のスポーツ動作の運動制御様式をみた研究で は、これまでサッカーボールのキック11), バレーボ ールのサーブ2), バドミントンのスマッシュ など, 多くの種目および動作課題が用いられている。これ らの研究では, 動作の熟練度の違いや, 運動習熟に よる運動学的変化もしくは電気生理学的変化をみる ことで, 熟練度による運動制御の相違を検討してい
る. 運動学的な変化を捉える指標としては, 動作中 の角度変位や角速度, 角加速度の変化, そして関節 トルクなどが用いられている。また, 電気生理学的 な変化を捉える指標としては筋電図（Electromyography：EMG）が用いられており，これらの指標か ら動作の制御様式の違いが明らかにされてきた。

このように，実際のスポーツ動作を課題として用 いた研究が多くある中で, 種々の球技で用いられて いるボールバウンシング動作に関する研究は少な い. ボールバウンシング動作は運動協調性, そして 巧緻性を評価する指標として，近年までは「ジグザ グドリブル」として体力・運動能力テストの一項目 として挙げられており, 一般的な動作課題として用 いられてきた。 また球技スポーツの中では, ボール バウンシング動作は実際の指導現場においても基礎 
的技能として位置づけられており, 試合の構成要素 としても大きな割合を占めている。泉ら ${ }^{4)}$ は, バス ケットボール試合中の攻撃パターンとしてのドリブ ル出現率は $32.0 \%$ \%゙り, 最も高い出現率である ワンミートシュート (49.5\%) の次に高い割合で あると報告している。よって，ドリブルというスキ ルの優劣が, バスケットボールの試合における勝敗 を左右する大きな要因であることが分かる。

これまでのバスケットボールのドリブル動作に着 目した研究として, Broderick \& Newell ${ }^{5)}$ は 4 歳か ら 22 歳までの熟練度の異なる対象を用い, ドリブ ル中の上肢の協調性の違いを検討した。 その結果,

熟練度によってドリブル中の上肢の関節における協 調性が異なっており，熟練者は高い協調性を保った 状態でのドリブル動作が可能であったが，未熟練者 は協調性を維持することができず，各関節の角度変 化の変動性が大きかったと報告している。しかし， 彼らの実験では最適な速度でのみドリブルを行って おり,ドリブル速度の違いや電気生理学的指標から の検討はされていない.

一方, スポーツ動作の熟練度の違いを電気生理学 的指標から捉えた研究として, Sakurai \& Ohtsuki ${ }^{3)}$ はバドミントンのスマッシュを課題として用い, 熟 練度による筋活動の違いを明らかにした。その中 で，熟練者はシャトルインパクトに対する筋活動の タイミングが適正化されており，より高いパフォー マンスの遂行が可能であったと報告している，また Bazzucchi $ら^{6)}$ は，テニス選手に等速性の肘伸展動 作課題を行わせたところ, テニス選手は非テニス選 手に比べて筋の同時収縮が少なかったと報告してい る. Osu ら $(2002)^{7)}$ は, この筋の同時収縮は関節 のスティフネスを表していると述べており，学習に よって高度で合目的的なスティフネス制御，すなわ ち動作課題に対して最適な筋活動へと調節すること でエネルギーの無駄を省き, 疲労を軽減させること が可能になることを示唆している。 また, 歩行 ${ }^{8} や$ サイクリング動作 ${ }^{9)}$ に扮ける動作速度の変化によっ ても筋活動様相が変化することが示されており, 動 作の速度条件によって運動制御様式が異なると報告 されている。
これらのことから，基礎的技能の一つとして用い られているボールバウンシング動作に関して, 速度 条件による運動制御様式の変容や熟練度による相違 を運動学的変化と電気生理学的変化から検討するこ とは，ヒトの動作スキルの解明および指導現場にお ける有力な情報を提供できると考えられる．

そこで本研究では, バスケットボール部員とボー ルバウンシング動作の未熟練者を対象とし, 異なる 速度条件下でのボールバウンシング動作を実施させ ることで, 速度条件や熟練度の違いによる関節ステ イフネス制御の相違を明らかにすることを目的とし た，運動学的指標には上肢関節の角度变位量を高速 度カメラによって記録し, 電気生理学的指標は筋電 図から上肢筋群の筋活動量および関節ごとの同時収 縮值を算出して，それらを関節スティフネスの評価 指標として速度条件㧍よび熟練度から検討した。

\section{2. 対象と方法}

\section{1 被験者}

上肢に障害などの既往歴がなく，健康で右利きの 男子大学生を被験者とした。現在大学のバスケット ボール部に所属している選手 9 名（19.9 0.8 歳, 競技歴 $9.8 \pm 2.2$ 年) をバスケットボール部群 (Basketball player ; 以下 B 群) とした。また,一 般男子大学生 6 名 (22.9 3.0 歳) を対照群 (Control；以下 C 群) とした。対照群はバスケット ボールの経験が体育の授業程度であった，実験内容 については, 筑波大学人間総合科学研究科研究倫理 委員会の承認の下,被験者に書面にて同意を得た。

\section{2 測定方法}

(1) 測定装置

被験者は, 上体の動きや姿勢が動作に影響しない ようにするため, 高さ調節が可能な椅子に座り, 個 人の最も快適な高さに調節してボールバウンシング 動作を行った。ボールバウンシング動作に使用する ボールには, バスケットボールの 7 号検定球（モル テン社製，MTB $7 \mathrm{WW}$ ）を用いた。ボールバウン シング動作は，床に置かれた目標上 $(20 \times 20 \mathrm{~cm})$ 
（2） ボールバウンシング動作の速度と熟練度の違いが関節スティフネスに及ぼす影響 23

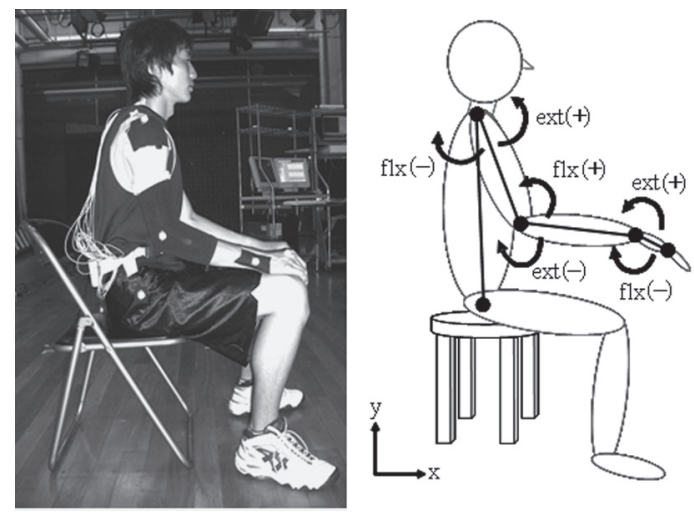

図 1 マーカー位置と各関節の角度定義（出典：執筆者）

でバウンドさせた。この目標の下はマットスイッチ になっており，ボールの接地，離地を記録できるよ うにした，また，視覚情報を統一するために，被験 者の $2 \mathrm{~m}$ 前方に注視点となる目印を置き, 動作課 題の実施中はその注視点を見るように教示した。

被験者は，予備実験より分類された次の 3 つの速 度条件でボールバウンシング動作を行うよう教示さ れた. 1つ目の速度はSlow 課題 $(80 \mathrm{bpm}), 2$ つ目 の速度は Prefer 課題（個人にとって最適な速度）, 3 つ目は Fast 課題 $(140 \mathrm{bpm})$ であった. Prefer 課題以外の 2 課題では, 外部の音刺激（電子メトロ ノーム）に同調させてボールバウンシング動作を行 うように指示した。

(2) 運動学データの収集および記録 動作中の運動学デー夕を記録するために，身体の 6 カ所に反射マーカーを取り付けた（図 1). 反射マ 一カーは, 上前腸骨棘, 肩峰, 肘頭, 茎状突起, 第 三中手骨頭，第三末節骨粗面（全て右側）に貼付 し，上前腸骨棘上－肩峰上－肘頭を結んだ線を肩関 節角度, 肩峰一肘頭 - 茎状突起を結んだ線を肘関節 角度, 时頭 - 茎状突起 - 第三中手骨頭を結んだ線を 手関節角度として，それぞれ定義した。これらの反 射マーカーを, 被験者の $5 \mathrm{~m}$ 側方に置かれた高速 度カメラ（ディテクト社製，HAS-220）によって, 毎秒 100 コマ, シャッタースピード $1 / 400$ 秒で撮影 した，映像はパーソナルコンピュータに記録し，動 作解析ソフト (Frame DIAS V3, ディケイエイチ 社製）の二次元 DLT 法を用いて, 二次元座標から
ボールバウンシング動作中の各関節の角度波形を求 めた。 その後, 各関節のデータは波形解析ソフト (Spike2，CED 社製）を用いて $20 \mathrm{~Hz}$ の Low-pass フィルタにて平滑化し, ボールの接地から次の接地 までを 1 サイクルとして全試行の時間軸を基準化し た。

(3) 電気生理学デー夕の収集抢よび記録

動作中の表面筋電図 (Surface electromyography, EMG）を上肢 6 筋から導出した. EMG は全員右側 の三角筋前部 (Anterior deltoid, AD), 三角筋後部 (Posterior deltoid, PD), 上腕二頭筋長頭 (Biceps brachii, BB)，上腕三頭筋長頭 (Triceps brachii, TB), 橈側手根屈筋 (Flexor carpi radialis, FCR), 尺側手根伸筋（Extensor carpi ulnaris, ECU) から 導出した. EMGの増幅器にはテレメータ (WEB - 5500, 日本光電社製, 感度 $0.2 \mathrm{mV} / \mathrm{div}$, 時定数 $0.03 \mathrm{~s}$ ，ハイカットオフ $500 \mathrm{~Hz}$ ) を用い, 電極はア クティブ電極 (SS-2096, 日本光電社製) を使用し た. 上腕部に接地電極 $(\mathrm{NM}-522 \mathrm{~S}$, 日本光電社製) を巻き付けた。課題動作中に導線の動きが邪魔にな らないよう, サージカルテープで導線をまとめ, 上 肢に着用するアームスリーブというサポーターによ って導線および電極部を固定した。また，LED ラ イトによって映像と EMG データに信号を入れるこ とで, 運動学デー夕と EMG デー夕を同期させた。

(4) 実験手順

実験に先立ち，各々の EMG を規格化するために 上肢 6 筋から徒手筋力検查法 (Manual muscle test, MMT）により等尺性最大随意笳収縮（Maximum voluntary contraction, MVC) 時の EMGを記録し た. MVC 時の EMG は休唕を挟んで 2 回計測し, その平均值を採用した。 その後, 被験者は椅子に座 り，目標上でのボールバウンシング動作を実施し た. 最初の数回は動作課題に慣れるために十分な練 習を行い, 本測定では課題の行いやすい Slow $\rightarrow$ Fast $\rightarrow$ Prefer の速度条件の順でボールバ ウンシング動作を実施した。なお，1回の試行は約 20 秒程度から成り立っており, 各速度条件での試 行は 3 回ずつ実施した。課題動作中に目標上でのバ ウンドができなくなった場合や, 外部の音刺激と同 
24 バイオメカニズム 20 —身体機能の補助と向上—

調させることができなくなった場合には，試行をや り直させた。条件間には十分な休息時間を設け，疲 労の影響が出ないようにした。

\section{3 データ解析および統計処理}

（1）デー夕解析

各試行に扔ける, ボールバウンシング動作の中で 最もリズム（ボールの接地から次の接地まで）が安 定している5サイクルの動作を解析の対象とした. LED ライトからの信号によって同期化された運動 学データと $\mathrm{EMG}$ データは, ボールの接地から接地 までを 1 サイクルとして両デー夕の時間軸を規格化 した（図 2)，そして，5 サイクル×3 試行 $=15$ サ イクルに损ける, 平均值および標準偏差を算出し た。また，ドリブル速度の指標として，1サイクル に要した時間の平均值から, 各速度条件におけるボ ールバウンシング動作の bpm を算出した.

運動学的指標として, 画像解析から得られた関節 の変位データより各関節の角度変位量を算出した。

関節の角度変位量は 1 サイクルにおける最大屈曲位
と最大伸展位の差の絶対值とした

(2) EMG データの解析

各 EMG は整流化した後, RMS (Root mean square, 二乗平均平方根）を算出した。 そして, 各 試行の RMS を予め計測した MVC 時の RMS で除 算し，100を乗算することで％MAXに変換した (図 2 の下段).

(3) 同時収縮值

各関節の動きに関わる屈筋 (flx) と伸筋 (ext) の筋活動から同時収縮值を算出した。屈筋と伸筋の 組み合わせは, 肩関節では $\mathrm{AD}-\mathrm{PD}$, 肘関節では BB-TB，手関節では FCU-ECR とした。各筋の\% RMS の值から, 関節のスティフネスや動作の経済 性を評価する指標として用いられている関節の同時 収縮值（Cocontraction index, CI）を，下記の Falconer \& Winter ${ }^{10)}$ の式により算出した.

$$
I_{a n t}=\int_{t 1}^{t 2} R M S_{f x x}(t) d t+\int_{t 2}^{t 3} R M S_{\text {ext }}(t) d t
$$

$t 1, t 2$ : 屈筋が伸筋より多く活動している区間

$t 2, t 3$ : 伸筋が屈筋より多く活動している区間
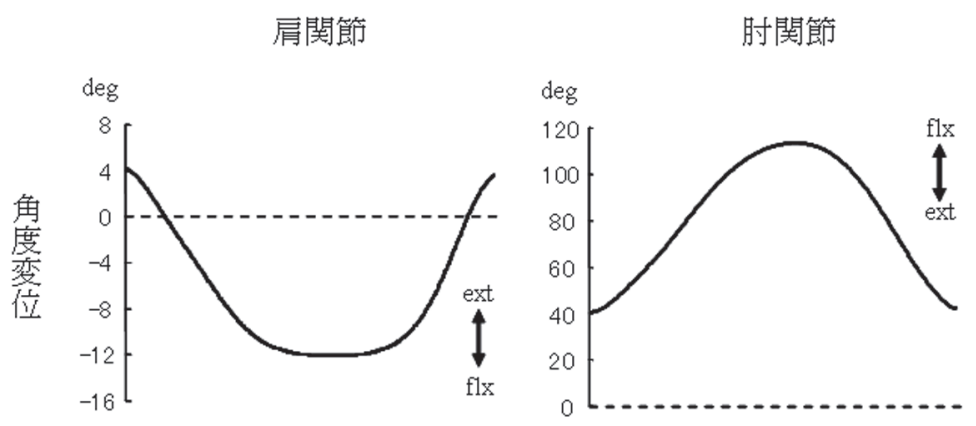

$$
\operatorname{deg}
$$
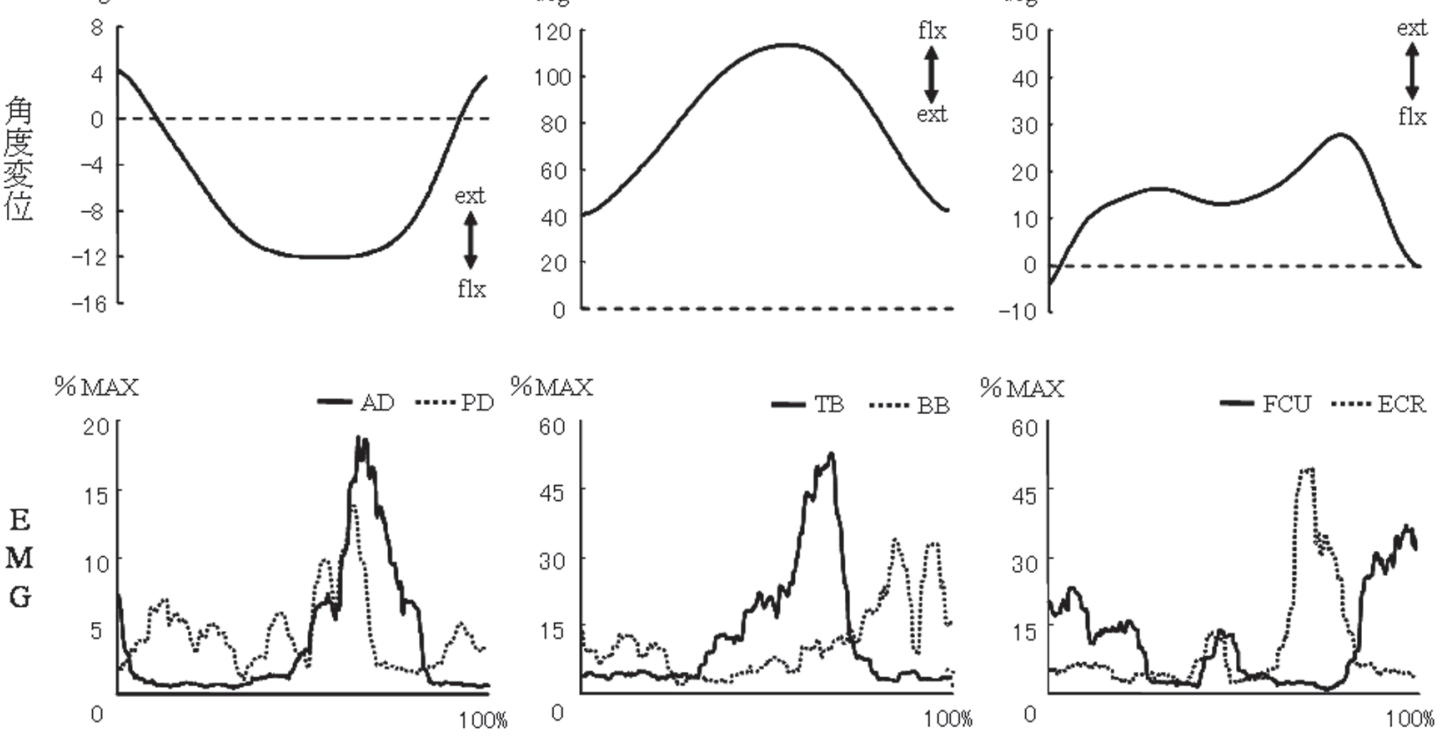

Normalized time

(1サイクルを100\%として規格化)

図 2 角度変位と $\mathrm{EMG}$ データの典型例（Prefer 課題）(出典：執筆者) 
$I_{\text {Total }}=\int_{t 1}^{t 3}\left[R M S_{\text {agon }}+R M S_{\text {ant }}\right](t) d t$

$t 1, t 3$ : 屈筋と伸筋の RMS の総和

$C I($ Cocontraction index $)=\frac{2 I_{\text {ant }}}{I_{\text {Total }}} \times 100[\%]$

\section{4 統計処理}

全被験者の各速度条件における運動学データおよ びEMG データは，それぞれの群で平均值を算出し 比較した。データの比較には, 統計処理ソフト (SPSS 11.0, SPSS 社製) を用いて，速度条件間お よび群間で二元配置の分散分析を行ったＦ值が有 意であった場合，その後の検定としてTukeyの HSD を用いて多重比較を行った。また，バスケッ トボール部群と対照群の比較には，対応のない t-testを行った。危険率は 5 \%未満とした。

\section{3. 結果}

\section{1 運動学データ}

各速度条件におけるバスケットボール部群（以下 B 群) と対照群（以下 C 群）のボールバウンシン グ動作のパフォーマンス（bpm）は, Slow 課題 (80 bpm) において B 群は $79.9 \pm 1.2$ bpm, C 群は $80.0 \pm 1.5 \mathrm{bpm}$ であり, Prefer 課題（個人にとっ て最適な速度）において B 群は $112.2 \pm 10.8$ bpm， C 群は $106.4 \pm 6.6 \mathrm{bpm}$ であり, Fast 課題 （140 bpm）に扔いて B 群は $140.1 \pm 2.1$ bpm，C 群 は $138.9 \pm 0.5 \mathrm{bpm}$ であった。 全ての速度条件にお いて群間に統計的な有意差はみられなかった。

各速度条件における課題中の各関節の角度変位量 を，1サイクルでの最大屈曲角度と最大伸展角度の 差から算出した，解析の結果， B 群は肩関節の角度 変位量がSlow 課題から Fast 課題で有意に増加し たが $\left(15.9 \rightarrow 17.4 \rightarrow 21.8^{\circ}\right), C$ 群に変化はみられな かった (図 3 上段)。肘関節に打いては, 両群とも に速度が速くなると角度変位量は減少していった (図 3 中段)。手関節では, 両群とも速度条件の変化 に伴う顕著な変化はみられなかった (図 3 下段). 群間での差をみてみると, B 群は C 群に比べて Slow 課題に扔ける手関節の角度変位量が大きかっ

\section{肩関節角度変位量}

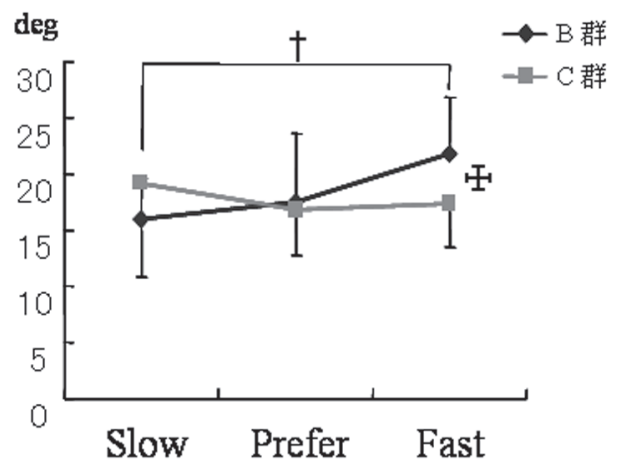

肘関節角度変位量
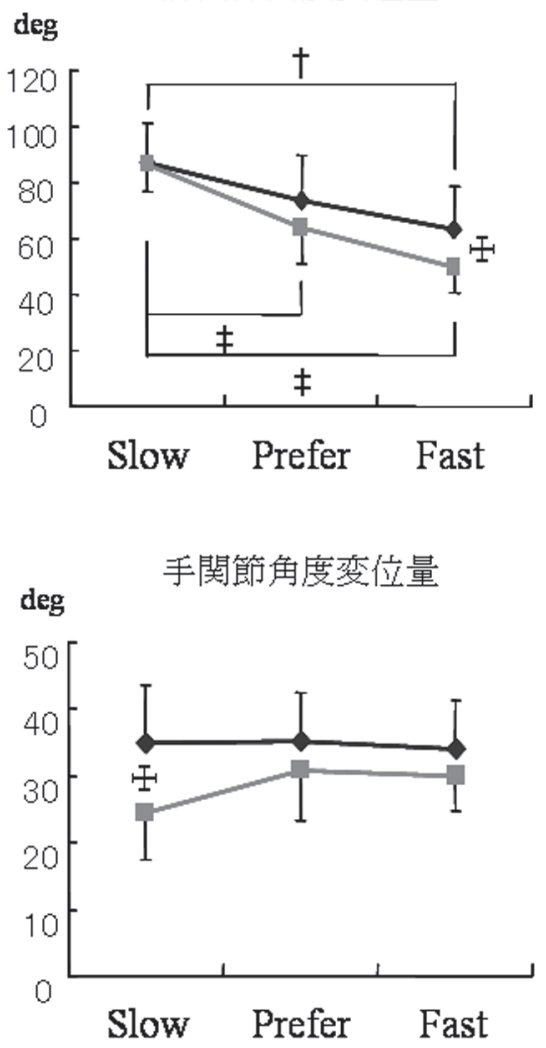

中：群間で有意差斿 $(p<0.05)$

†：B群速度条件間で有意差あり $(p<0.05)$

キ：C群速度条件間で有意差あり $(p<0.05)$

図 3 速度条件による各関節の角度変位量の变化（出典：執 筆者) 
肩関節 $\mathrm{EMG}$
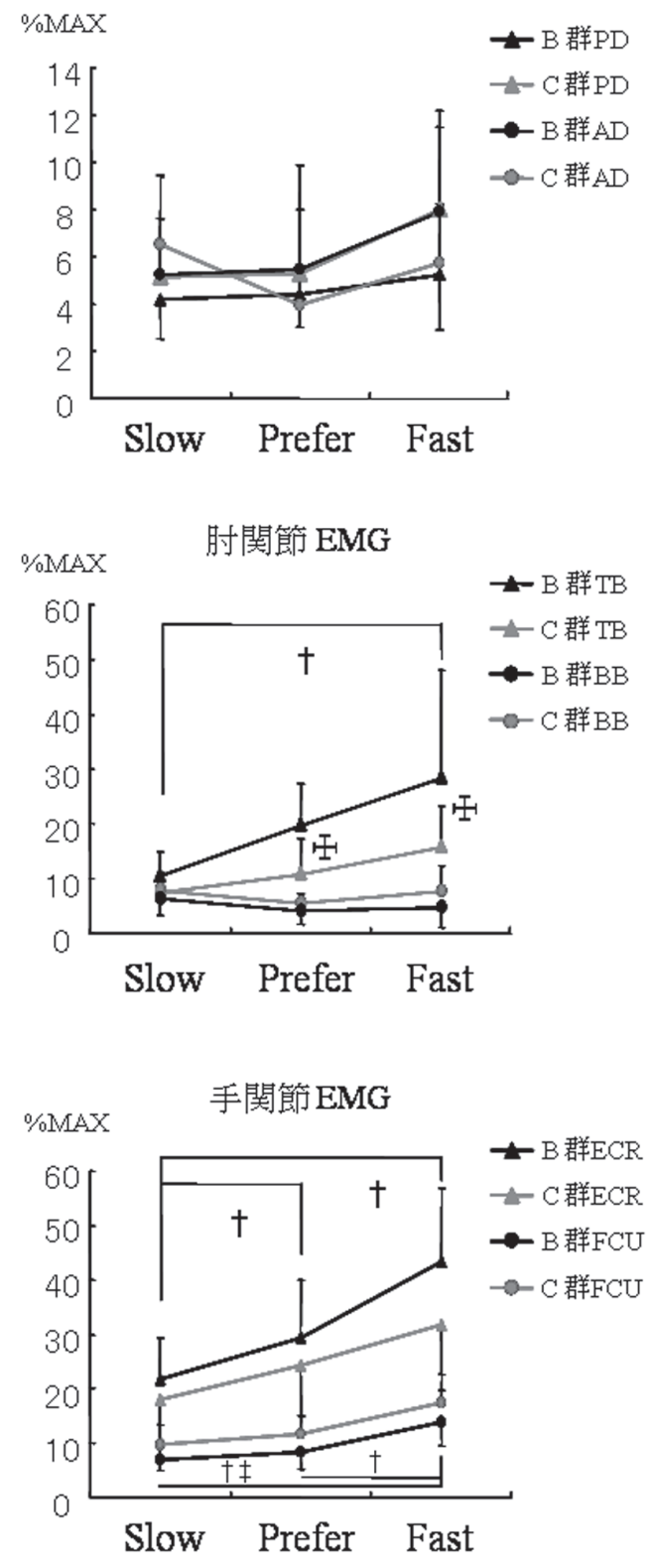

ゆ：群間で有意差あり $(p<0.05)$

$\dagger$ † B群速度条件間で有意差あり $(p<0.05)$

キ：C群速度条件間で有意差あり $(p<0.05)$

図 4 速度条件による各関節の $\mathrm{EMG}$ の変化（出典：執筆者）
肩関節 CI
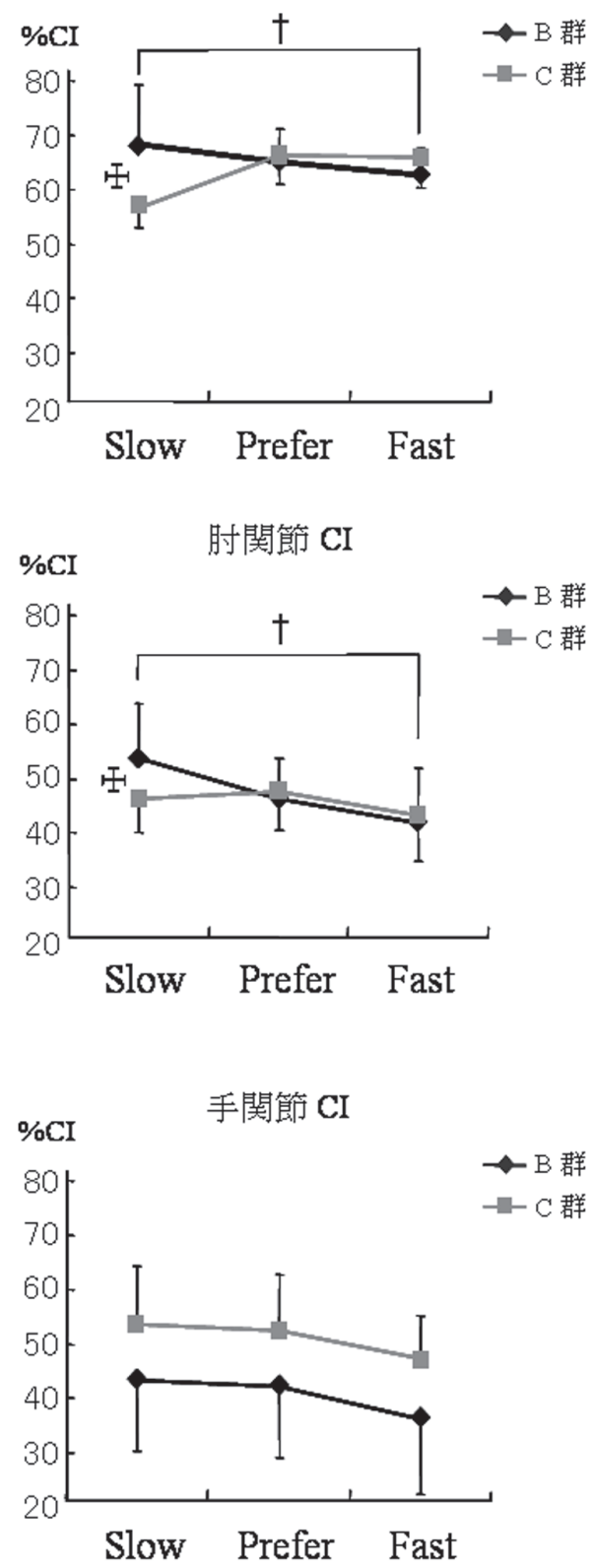

$\Psi$ : 群間で有意差和り ( $0<0.05)$

$\dagger$ ： B群速度条件間で有意差的り ( $0<0.05)$

図 5 速度条件による各関節の CI の変化（出典：執筆者） 
（2）ボールバウンシング動作の速度と熟練度の違いが関節スティフネスに及ぼす影響 27

た $\left(34.9 \mathrm{vs} 24.3^{\circ}\right.$, 図 3 下段)。また, B 群は C 群 に比べて Fast 課題での肩関節および肘関節におけ る角度変位量が大きかったが (肩関節 21.8 vs $17.4^{\circ}$, 肘関節 63.3 vs $\left.49.6^{\circ}\right)$, Prefer 課題では両群の角度 変位量に差はみられなかった（図 3 上段，中段）。

\subsection{EMG データ}

ボールバウンシング動作において, 動作速度が増 加すると各筋活動量は増加する傾向にあった（図 4). 速度条件および群間での肩関節の筋活動に有意 な違いはみられなかった（図 4 上段）。一方，群間 での比較をすると, Prefer と F ast 課題において B 群は C 群より有意に高い TB の筋活動量を示した (29.1 vs 15.7 \% MAX, 図 4 中段)。また, B 群で はSlow-Fast 課題にかけて BB と ECR の筋活動が 有意に増加し, C 群は ECR のみ増加した（図4下 段).

\section{3 同時収縮值 (CI)}

速度条件の変化に伴い同時収縮值 CI は減少傾向 にあった（図 5)，速度条件の変化に伴い，B 群で はS Slow 課題から Fast 課題にかけて肩関節 CI およ び肘関節 CI が有意に減少した（図 5 上段，中段）. 一方, C 群では速度条件による CI の変化はみられ なかった、また，群間でのCIを比較すると, Slow 課題の肩関節と肘関節 $\mathrm{CI}$ において, B 群が C 群よ り有意に高い CI を示した（図 5 上段，中段）。ま た，手関節の Fast 課題では $\mathrm{B}$ 群が $\mathrm{C}$ 群より有意に 低いCI であった（46.0 vs 35.1％CI, 図 5 下段).

\section{4. 考察}

本研究の目的はボールバウンシング動作の速度条 件が運動学的, 電気生理学的に及ぼす影響を明らか にすることであった。また，被験者をバスケットボ ール部群 (B 群) と対照群 (C 群) に群分けするこ とで熟練度による違いを検討した。

\section{1 速度条件の変化に伴う運動学的変化}

本研究で用いた 3 つの速度条件は, Slow 課題が
$80 \mathrm{bpm}$, Prefer 課題は個人の最適な速度, Fast 課 題は $140 \mathrm{bpm}$ であった。 バスケットボール部群（B 群）と対照群（C群）の群間で, それらの速度条件 でのパフォーマンスに違いはみられなかった。本課 題は, メトロノームの音に合わせるという課題であ ったことや，座位での上肢に限定した動作であった ために，比較的容易に速度条件に合わせることがで きたと考えられる。このことから，両群とも全ての 速度条件で同様のボールバウンシング動作を達成し ていた。しかしながら，その際の運動学的指標と筋 活動様相は異なっていた。

運動学的な指標として関節の角度変位量を算出 し、ボールバウンシングの動作速度の違いがどのよ うに関節の角度変位量に影響を及ぼすかを検討し た。その結果, 動作速度が上昇すると B 群の肩関 節の角度変位量は増加し, 一方で B 群と C 群の肘 関節の角度変位量は減少した (図 3 上段, 中段). これは, 動作速度の変化に伴って各関節の角度変位 量を増減させる, いわゆる自由度 (Degree of freedom）の調節が関係していると考えられる. Morrison $ら^{8)}$ は, 拍手の速度を徐々に増加させる課 題を行わせたところ, 徐々に動作振幅が減少してい ったと報告している。また古屋ら ${ }^{11)}$ は, ピアノの打 鍵動作のテンポを増加させたときの上肢の関節角度 変化を解析したところ, 角度変位量は近位の関節が 遠位の関節よりも大きく減少したと述べている。本 実験の結果でも, 特に肘関節に扔いては先行研究と 同様の結果が得られた。しかし, 動作速度が上昇す ると $\mathrm{B}$ 群の肩関節の角度変位量は増加していた（図 3 上段)。これはボールバウンシング動作の特徴と して, 跳ね返ってきたボールを「緩衝」する作用が 肩関節で働いていたと推測される。動作速度が上昇 すると跳ね返ってくるボールの速度も大きくなるた め, B 群は勢いを緩衝して次のバウンドへとスムー ズにつなげるために, 肩関節を「緩衝」, 肘関節を 「速度調整」として役割を分化させていたため, 肩 関節の角度変位量は増加したと考えられる。

また群間での差をみると, Slow 課題におけるC 群の手関節の角度変位量は B 群に比べて少なく, また F a st 課題における肩関節および肘関節の角度 
変位量も B 群に比べて有意に少なかった（図 3 上 段，下段）。これは，Broderick \& Newell ${ }^{5)}$ が報告 しているように，余分な自由度を少なくし動作の変 動性を減少させる制御を C 群は行っていたと考え られる。また速度が増加すると，B 群に比べて C 群では肘関節の角度変位が有意に少なかった（図 3 中段). Meulenbroek ${ }^{12)}$ は, 描画運動において運 動周波数の高い運動を行うときは，より遠位で慣性 モーメントの小さい手部による振動運動を行うと報 告しており，C 群も同様に遠位の手関節の貢献度を 高めることで速度の増加に対応していたと考えられ る.これらの各関節の機能的役割の違いは, 熟練群 は自由度を「開放」することで動作の効率性を向上 させ，未熟練群は自由度を「凍結」することで動作 の変動性を減少させるという, 制御戦略の違いを捉 えていると推測される.

\section{2 速度条件の変化に伴う筋活動量の変化}

動作速度の増加によって, $\mathrm{B}$ 群の $\mathrm{TB}$ および $\mathrm{B}$ 群と C 群での手関節の筋活動量が有意に増加した (図 4 中段, 下段)。Yamazaki ら ${ }^{13)}$ は, 肘伸展動作 における加速度の増加と TB の筋活動量の増大は相 関関係にあると報告している。本実験においても， B 群はより高い TB の筋活動によって大きな伸展加 速度を生成して抢り，その貢献によって Fast 課題 に㧍ける高速度動作を実行していたと考えられる。 また手関節の筋活動をみると, B 群は動作速度の増 加に伴い ECR と FCU の筋活動が高くなっており, 手関節も TB と同様に動作速度の増加に対して重要 な役割を担っていたと推測される (図 4 下段)。一 方, C 群では FCUのみの活動が顕著に増加してお $り$, 手関節の背屈方向への筋活動が比較的少なかっ た。このことから，C群は主に掌屈動作を主体とし て高速度動作を実行していたと考えられる。

\section{3 速度条件の変化に伴う $\mathrm{Cl}$ の変化}

同時収縮值 $(\mathrm{CI})$ の変化をみると, 動作速度の 増加によって B 群のみにおいて肩関節と肘関節の CI が減少していった（図 5 上段，中段）。このよう

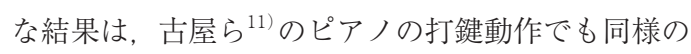

傾向がみられた。これは, Fast 課題時においては 高周波数の運動を実行するために, ブレーキとなる 同時収縮を減少させることで遠位部の関節の可動性 を維持していたと考えられる。しかし，C群では CI の変化はみられず，特に手関節では B 群に比べ て高い同時収縮レベルでの動作を行っていた，Osu ら $(1999)^{14)}$ は, 筋の同時収縮は関節スティフネス と相関があると報告しており， B 群は $\mathrm{C}$ 群に比べ てょり低い関節スティフネスでの動作遂行が可能で あったことから，より効率的な筋活動の調節によっ て，エネルギー効率的にも優れた動作を遂行してい たと推察される。一方 Gribble ら ${ }^{15)}$ は, 高い同時収 縮によるスティフネスの増加は動作の正確性を高め ると報告しており，C群はボールバウンシング動作 の正確性を維持, 向上させたために高い CI が表れ たと考えられる。

\section{4 速度条件による角度変位量と $\mathrm{Cl}$ の関係性}

各速度条件の角度変位量と CI の関係性を定性的 に表すために，図 3 中段および図 5 中段において定 量的に示した各速度条件における角度変位量と CI を，群別にプロットした（図 6)。なお，ここでは 速度条件によって顕著に変化していた肘関節のみを 示した， B 群は速度条件が速くなるほど肘関節の角 度変位量およびCI は徐々に減少していき, 全体的 に左下へとデータが移行したことが分かる（図 6 上 段，B 群の矢印)。一方， C 群に関しては CI に変化 がなく, 肘関節の角度変位量のみが減少しており, デー夕は真下へのみ移行していた（図6下段, C 群 の矢印)。よって, B 群は速度条件の増加に伴い同 時収縮量を減少させ, ボールバウンシング動作の速 度変化に伴い関節スティフネスを調節できていたこ とが定性的に示された。熟練度によるこの関節ステ イフネス制御の違いは，熟練者は主働筋と拮抗筋の 活動交代を明確にしてより滑らかな動作遂行を可能 にしていたのに対し，初心者は主働筋と拮抗筋の同 時的な活動によって, 動作の正確性を向上させてい たと考えられる。 


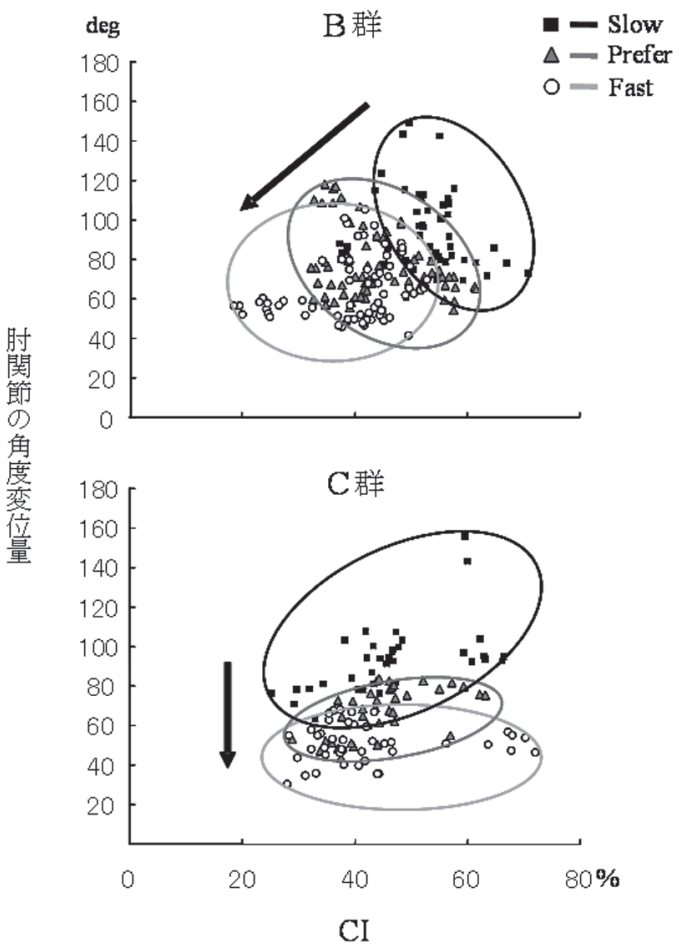

図 6 肘関節の角度変位量と CI の関係性の変化（円は $95 \%$ 信頼楕円を表す）（出典：執筆者）

\section{5. 結論}

本研究の目的はボールバウンシング動作の速度条 件および熟練度が運動学的, 電気生理学的指標に及 ぼす影響を明らかにすることであった。その結果, 速度条件の変化に伴う運動学データの変化として, 動作速度が上昇すると B 群の肩関節の角度変位量 は増加し, B 群と C 群の肘関節の角度変位量は減 少した。また群間での差をみると，Fast課題にお ける肩関節および肘関節の角度変位量は, B 群に比 べて C 群は顕著に少なかった。これらの違いは, 動作速度の変化に伴う肩関節や肘関節の機能的役割 や自由度の調節が熟練度によって異なることを示唆 している。

筋活動量の変化をみると, 動作速度の増加によっ て $\mathrm{B}$ 群の $\mathrm{TB}$ および $\mathrm{B}$ 群と $\mathrm{C}$ 群での手関節の筋活 動量が有意に増加しており，課題遂行における筋の 動員パターンが異なることが明らかとなった。また
同時収縮值の変化は, 動作速度の増加に伴う肩関節 と时関節の CI の減少が B 群のみにおいて捉えられ た。一方, C 群では CI の有意な変化はみられず, B 群は C 群より低い関節スティフネスでの動作が 可能であったと考えられる。このように，速度条件 を変化させることによって群間のスティフネス制御 の違いを明確に捉えることができた。

これらの運動学データと CI の関係性から, B 群 は C 群に比べて速度条件に対する関節スティフネ スを合目的的に調節し，よりエネルギー効率的に優 れた動作の遂行が可能であったことが示された。 そ して，このような関係性の変化を捉えることで, 様々な動作課題におけるスティフネス制御の変化や 特徵をより明確に捉えることが可能になるだろう. 今後, さらに広範な環境条件やスキルレベルで比較 することで，より詳細の制御様式が明らかになるこ とが期待される.

\section{参考文献}

1) Chow, Y.J., Davids, K., Button, C., Koh, M.: Coordination changes in a discrete multi-articular action as a function of practice, Acta Psychol, 127, 163-176, (2008).

2) Temprado, J., Della-Grasta, M., Farrell, M., Laurent, M. A novice-expert comparison of (intra-limb) coordination subserving the volleyball serve, Hum Mov Sci, 16, 653-676, (1997).

3) Sakurai, S., Ohtsuki, T.: Muscle activity and accuracy of performance of the smash stroke in badminton with reference to skill and practice. J Sports Sci, 18(11), 901914, (2000)

4）泉圭祐, 石川武, 清水義明, 木村和宏, 塔尾武夫：バス ケットボールのルール改正に打ける攻撃パターンの比 較: 2000,2001 年全日本男子学生バスケットボール選手 権の試合分析から, 日本体育学会大会号, 53, 526, (2002).

5) Broderick, P.M., Newell, M. K.: Coordination Patterns in Ball Bouncing as a Function of skill, J Mot Behav, 31 (2), 165-188, (1999).

6) Bazzucchi, I., Riccio, M. E., Felici, F.: Tennis players show a lower coactivation of the elbow antagonist muscles during isokinetic exercises, I Electromyogr Kinesiol, 18, 752-759, (2008)

7) Osu, R., Franklin, D.W., Kato, H., Gomi, H., Domen, K., Yoshioka, T., Kawato, M.: Short-and long-term changes in joint $\mathrm{co}^{-}$contraction associated with motor learning as revealed from surface EMG, $J$ Electromyogr Kinesiol, 88(2), 991-1004, (2002).

8) Morrison, S., Hong, S. L,. Newell, K. M.: Upper frequency limits of bilateral coordination patterns. Neurosci Lett, 454, 233-238, (2009). 
9) Chapman, R.A., Vicenzino, B., Blanch, P., Hodges, W, P.: Pattern of leg muscle recruitment very between novice and highly trained cyclists, J Electromyogr Kinesiol, 18 , 359-371, (2008)

10) Falconer, K. and Winter, D.: Quantitative assessment of Co-contraction at the ankle joint during walking, Electromyogr Clin Neurophysiol, 25, 135-149, (1985).

11）古屋晋一, 青木朋子, 木下博：熟練ピアニストによるピ アノの打鍵テンポと音量の調節に関わる運動制御, バイ オメカニズム学会誌, 30(3)，151-155, (2006).

12) Meulenbroek, R.G. J., Rosenbaum, David A., Thomassen, A.J.W.M. and Schomaker, L.R.B.: Limb-segment selection in drawing behavior, Q J Exp Psychol A, 46(2),
273-299, (1993)

13) Yamazaki, Y., Suzuki, M., Itoh, H., Ohkuwa, T.: Rapid acceleration of the lower arm correlates with agonist EMGs during the initial phase, Hum Mov Sci, 21, 259272, (2002)

14) Osu, R. and Gomi, H.: Multijoint muscle regulation mechanisms examined by measured human arm stiffness and EMG signals, J Neurophysiol, 81, 1458-1468, (1999).

15) Gribble, P.L., Mullin, L. I., Cothros, N., Mattar, A., Role of cocontraction in arm movement accuracy. J Neurophysiol, 89, 2396-2405, (2003).

\title{
Effect of Skill Level and Joint Stiffness on Ball-Bouncing Tasks at Different Speeds
}

\author{
Masato IWAMI $^{1 \dagger}$, Tomohiro KIZUKA ${ }^{2}$ \\ ${ }^{1}$ University of Tsukuba, Doctoral Program in Health and Sports Science \\ ${ }^{2}$ University of Tsukuba, Graduate School of Comprehensive Human Sciences
}

\begin{abstract}
In this study, we investigated the influence of kinematics and electromyographic variability on a ball-bouncing task under different speed conditions. Expert and novice subjects carried out ball-bouncing tasks at three speed conditions, and we examined the differences between expert and novice subjects' bouncing movements in terms of the amplitude of the angular displacement of the upper limb and the muscle activity. Subjects were instructed to synchronize their ball-bouncing movements with three speeds (Slow, Prefer, Fast) via an external audio signal. The angular variations of the three joint angles of the upper limb and electromyograms (EMGs) were recorded, and the cocontraction index (CI) of agonist and antagonist muscle activity for each joint was calculated. The amplitude of angular displacement and the EMG of each muscle were varied by increasing the bouncing speed, which mainly increased the activity of the elbow and wrist muscles. The CI for an expert's wrist in the fast-speed condition was less than that of a novice. Moreover, the relationship between elbow angle and the corresponding CI of the elbow was different for an expert and a novice subject. The results of this study indicate that experts bounce a ball with less joint stiffness and perform more efficiently in fast-speed conditions.
\end{abstract}

Key Words: Ball bouncing, Speed, EMG, Cocontraction, Joint Stiffness 